\title{
Website Blocking, Injunctions and Beyond: View on the Harmonization from the Netherlands*
}

\author{
Martin Husovec, Lisa van Dongen
}

\section{Introduction}

Very few provisions of the European Union intellectual property enforcement framework are subject to so many preliminary references as orders against intermediaries. In the area of IPR enforcement, the typical cases are disputes touching upon their roles. ${ }^{1}$ It is hard to deny that the Internet case law is a driving force behind much of the methodological and conceptual decisions in the CJEU's IPR enforcement agenda. In particular, the CJEU's application of the general limitations of remedies is becoming a focal point of many preliminary references, which is arguably a realization of the fact that Union law might provide a harmonized remedial ceiling. ${ }^{2}$

The website blocking case law is also an interesting case study from the perspective of the European harmonization. It shows how harmonisation by a halo effect can work. The widelypublicized use of a particular enforcement measure is replicated country-by-country, by a homogeneous group of stakeholders, thereby testing the local implementations and bringing its elements to the public scrutiny. The resulting picture painted by the domestic website blocking cases then reflects the state of Union harmonization.

\footnotetext{
* This contribution expands on the talk delivered by Martin Husovec at the 7th GRUR Int/JIPLP Joint Seminar, which was held at the Humboldt University of Berlin on 14 November 2016.

- Martin Husovec is an Assistant Professor at the Tilburg University (Tilburg Institute for Law, Technology and Society \& Tilburg Law and Economics Center); Lisa van Dongen is a LLM student and a research assistant at Tilburg Law School.

${ }^{1}$ Case C-275/06 Promusicae [2008] ECR I-00271, Case C-324/09 L'Oréal v eBay [2011] ECR I-06011, Case C360/10 SABAM (ECJ 16 February 2012), Case C-70/10 Scarlet Extended [2011] ECR I-11959, Case-484/14 Mc Fadden (ECJ 15 September 2016), Case C-494/15 Tommy Hilfiger (ECJ 7 July 2016), Case C-610/15 Stichting BREIN, Case C-314/12 UPC Telekabel Wien (ECJ 27 March 2014).

${ }^{2}$ See for the discussion: Martin Husovec, 'Injunctions Against Innocent Third Parties: Case of Website Blocking' (2013) 4 JIPITEC 116 (discussing the ceilings); Reto Hilty, 'The Role of Enforcement in Delineating the Scope of IP Rights' (2015) Max Planck Institute for Innovation \& Competition Research Paper No. 15-03 (discussing the ceilings)
} 
This piece contributes to the growing scholarship mapping the national post-implementation phase. ${ }^{3}$ It proceeds as follows. Part 1 gives a primer on Union law regarding injunctions against intermediaries. Part 2 explores the situation under the Dutch 'localization' of Union law, focusing particularly on injunctions, including against intermediaries, right to information and reimbursement of the costs. Part 3 explains the recent litigation chain concerning the website blocking and puts it in the broader context of discussions. Part 4 contrasts these findings with the situation under European Union law and practice in the other Member States. Part 5 concludes by evaluating the existing state of the harmonization in the area.

\section{Primer on injunctions against intermediaries}

Despite failing to address secondary liability, or perhaps to overcome this failure, the Union law legislates certain availability of injunctions against intermediaries, regardless of whether or not they may be considered secondary liable under the applicable national law. These rules are included in Art. 8(3) InfoSoc Directive (for copyright and related rights), ${ }^{4}$ Art. 11 of the Enforcement Directive (for other intellectual property rights) ${ }^{5}$ and Art. 63(1) Agreement on the Unitary Patent Court (for the Unitary patent). ${ }^{6}$ All of these provisions use basically identical

\footnotetext{
${ }^{3}$ P. Sirinelli, "Chronique de Jurisprudence - Mise à la disposition illicite d'oeuvres par l'intermédiaire des réseaux numériques" (2011) 228 Revue Internationale du Droit d'Auteur 287; Savola Pekka, 'Proportionality of Website Blocking: Internet Connectivity Providers as Copyright Enforcers' (2014) 5(2) JIPITEC 116; P. Savola, Internet Connectivity Providers as Involuntary Copyright Enforers: Blocking Websites in Particular (IPR University Center, 2015); M. Husovec, 'Injunctions Against Innocent Third Parties: Case of Website Blocking' (2013) 4 JIPITEC 116; A.Marsoof, 'The Blocking Injunction - A Critical Review of Its Implementation in the United Kingdom Within the Legal Framework of the European Union' (2015) 46 IIC 632, 656; K.T. O'Sullivan, 'Enforcing copyright online: Internet service provider obligations and the European Charter of Human Rights' (2014) E.I.P.R. 36(9); L. Feiler, 'Website Blocking Injunctions under EU and U.S. Copyright Law—Slow Death of the Global Internet or Emergence of the Rule of National Copyright Law?' (2012) TTLF Working Papers No. 13; 369; M. Husovec, 'CJEU Allowed Website Blocking Injunctions With Some Reservations' (2014) 9 (8) Journal of Intellectual Property Law \& Practice 63; J. Nordemann, 'Internetpiraterie: High Court of Justice bejaht Anspruch von Markeninhabern auf Website-Sperrung - Eine Option auch für deutsche Rechteinhaber?' [2014] GRUR-Prax 513, 515; M. Leistner and K. Grisse, 'Sperrverfügungen gegen Access-Provider im Rahmen der Störerhaftung (Teil 2)' [2015] GRUR 105; F. Hofmann, 'Markenrechtliche Sperranordnungen gegen nicht verantwortliche Intermediäre' [2015] GRUR 123, 128; D. Meale, 'NewzBin2: the first section 97A injunction against an ISP' (2011) 6 Journal of Intellectual Property Law \& Practice 854-857; H. Hjördis, 'Enforcement of Copyright' (2004) 47 Scandinavian Studies in Law 168; S. Jakobsen, 'Injunctions Against Mere Conduit of Information Protected by Copyright - A Scandinavian Perspective' (2011) IIC 151; S. Jakobsen, 'Mobile Commerce and ISP Liability in the EU' (2011) 1 International Journal Law Information Technology 46; G. Spindler, 'Sperrverfügungen gegen Access-Provider - Klarheit aus Karlsruhe?' GRUR 2016 Heft 5, 451 - 456; E. Rosati, Intermediary IP Injunctions in the EU and UK Experiences: When Less (Harmonization) is More? (2016) GRUR International (forthcoming)

${ }^{4}$ Directive 2001/29/EC of the European Parliament and of the Council on the harmonisation of certain aspects of copyright and related rights in the information society (OJ L 167/10) ('InfoSoc Directive')

${ }^{5}$ Directive 2004/48/EC of the European Parliament and of the Council of 29 April 2004 on the enforcement of intellectual property rights ('Enforcement Directive')

${ }^{6}$ Agreement on a Unified Patent Court (2013) OJ C 175, p. 1-40
} 
wording requiring that member States shall also ensure that rightholders are in a position to apply for an injunction against intermediaries whose services are used by a third party to infringe an intellectual property right. Art. 8(3) InfoSoc Directive and Art. 11 of the Enforcement Directive do not harmonize the exact conditions for such injunctions; these are left for the Member States. ${ }^{7}$

Following the Tommy Hilfiger case, 'It is settled case-law that [these provisions oblige] Member States to ensure that an intermediary whose services are used by a third party in order to infringe an intellectual property right may, regardless of any liability of its own in relation to the facts at issue, be ordered to take measures aimed at bringing those infringements to an end and measures seeking to prevent further infringements'. ${ }^{8}$ This means that, as a matter of Union law, in order to establish a course of action, the plaintiff has to prove the following elements: (a) the defendant is an 'intermediary', (b) 'whose service are used by a third party', (c) 'to infringe an intellectual property right'. The Member States may, however, deviate from these conditions.

\section{Enforcement Directive Enters Dutch Law}

When looking at the historical process of the development of intellectual property law in the Netherlands, the Dutch were not always exactly the first to jump on the harmonization bandwagon. After signing the Berne Convention, it took the government 30 years to implement it. ${ }^{9}$ Between 1869 and 1910, the Netherlands even temporarily repealed its patent system. ${ }^{10}$ Therefore, it does not come as a surprise that eleven years ago, when the term for the implementation of the Enforcement Directive ${ }^{11}$ expired, the Netherlands was one of the many Member States that missed the deadline. ${ }^{12}$ Why was that?

\footnotetext{
${ }^{7}$ Recital 59 of the InfoSoc Directive ("The conditions and modalities relating to such injunctions should be left to the national law of the Member States."); Recital 23 of the Enforcement Directive ("The conditions and procedures relating to such injunctions should be left to the national law of the Member States."); See also Scarlet Extended C-70/10 (ECJ, 24 November 2011), para 32 and Netlog C-360/10 (ECJ, 16 February 2012), para 30.

${ }^{8}$ Case C-494/15 Tommy Hilfiger Licensing and Others (ECJ, 7 July 2016) para 23

${ }^{9}$ F.W. Grosheide, Monografieën BW: Intellectuele Eigendom (A32 edn Kluwer Deventer 2011) p. 11; P.G.F.A. Geerts, Bescherming van de Intellectuele Eigendom, (10 th edn Kluwer 2013) p. 19.

${ }^{10}$ F.W. Grosheide, Monografieën BW: Intellectuele Eigendom (A32 edn Kluwer Deventer 2011) p. 11; RVO Nederland, 'Geschiedenis van octrooien'. Retrieved on 10 March 2017 from $<$ http://www.rvo.nl/onderwerpen/innovatief-ondernemen/octrooien-ofwel-patenten/wettelijketaken/octrooigeschiedenis/geschiedenis-van-octrooien>.

${ }^{11}$ Directive 2004/48/EC of the European Parliament and of the Council of 29 April 2004 on the enforcement of intellectual property rights (OJ L 157/45).

12 Commission Staff Working Document SEC(2010) 1589 final: Analysis of the application of Directive 2004/48/EC of the European Parliament and the Council of 29 April 2004 on the enforcement of intellectual property rights in the Member States Accompanying document to the Report from the Commission to the Council, the European Parliament and the European Social Committee on the application of Directive 2004/48/EC of the
} 
The final draft of the Enforcement Directive received heavy critique in the Netherlands: it was considered superfluous by Dutch experts in the field of intellectual property law, and not very innovative compared to the existing domestic legal scheme as well as the TRIPs Agreement. ${ }^{13}$ In addition, many commentators took the view that no considerable adaptation of existing law was necessary. ${ }^{14}$ However, despite the vigorous debates on the matter, the Netherlands actually did initiate the consultations with interested groups and the procedures for implementation early on, but just failed to complete most of them in time..$^{15}$ Eventually, only the Dutch Patent Act $^{16}$ was amended before the expiration of the implementation term when Articles 8-11, 13 and 15 of the Enforcement Directive ${ }^{17}$ were implemented by an amendment in February $2006 .{ }^{18}$ A number of justifications were offered to explain this delay. Although it is still not clear what the decisive factors were, the most likely reason was the unclear meaning of some the new obligations, as well as the number of separate acts in the Dutch legal scheme that needed to be reviewed and possibly amended. ${ }^{19}$

After twenty 'infringements for non-communications' were established by the Commission, amongst which one concerned the Netherlands, ${ }^{20}$ all other domestic acts in the field of intellectual property law were also amended. By the amendment of March 2007, Articles 1, 2, 5-11, and 13-15 of the Enforcement Directive were implemented into the new Title 15 of the Third Book of the Dutch Code of Civil Procedure ${ }^{21}$ and the separate acts on intellectual

European Parliament and the Council of 29 April 2004 on the enforcement of intellectual property rights COM(2010) 779 final, p. 27.

13 G. Cumming, M. Freudenthal and R. Janal, Enforcement of Intellectual Property Rights in Dutch, English and German Civil Courts (Kluwer Law International, Alphen aan den Rijn 2008) p. 90; C. Gielen, 'De Richtlijn Handhaving IE-Rechten' (2005) NTER, p. 10-11; M. Driessen, 'De willekeur van de proceskostenveroordeling' (2007) BIE, p. 344.

14 C. Gielen, 'De Richtlijn Handhaving IE-Rechten' (2005) NTER, pp. 6-11; G. Cumming, M. Freudenthal and R. Janal, Enforcement of Intellectual Property Rights in Dutch, English and German Civil Courts (Kluwer Law International, Alphen aan den Rijn 2008) pp. 90-93.

15 G. Cumming, M. Freudenthal and R. Janal, Enforcement of Intellectual Property Rights in Dutch, English and German Civil Courts (Kluwer Law International, Alphen aan den Rijn 2008) p. 89.

16 Rijksoctrooiwet 1995.

17 These Articles contain the "Right to information", "Provisional and precautionary measures", "Corrective measures", "Injunctions", "Damages" and "Publication of judicial decisions".

18. However, the law of 16 February 2006 implementing the Enforcement Directive into the Dutch Patent Act has been withdrawn on 30 June 2008 and replaced. Staatsblad 2006, No. 135 and 218.

${ }^{19}$ G. Cumming, M. Freudenthal and R. Janal, Enforcement of Intellectual Property Rights in Dutch, English and German Civil Courts (Kluwer Law International, Alphen aan den Rijn 2008) pp. 89-90.

${ }^{20}$ Commission Staff Working Document SEC(2010) 1589, p. 27.

21 These Articles contain the 'Subject matter', 'Scope', 'Presumption of authorship or ownership', 'Evidence', 'Measures for preserving evidence', 'Right to information', 'Provisional and precautionary measures', 'Corrective measures', 'Injunctions', 'Damages' and 'Publication of judicial decisions'. 
property rights. However, Articles 3, 4 and 12 of the Enforcement Directive were still not implemented. ${ }^{22}$ Most of these articles were already partially covered by existing articles in either the Dutch Code of Civil Procedure or in (some of) the separate acts. ${ }^{23}$ As a consequence, most of the Articles of Title 15 are lex specialis with respect to the general framework of the Dutch Code of Civil Procedure and separate intellectual property acts. ${ }^{24}$ The newly added provisions open up the relevant pre-existing Articles to a more Directive-conform interpretation or add some elements.

According to numerous Dutch legal scholars, the most important additions were those concerning the preservation of evidence, the ex parte interlocutory injunctions, and the costreimbursement rules, based on which the successful party would be fully remunerated by the unsuccessful one for its 'reasonable and proportionate legal costs and other expenses' ${ }^{25}$ The addition of the compensation rule is of particular importance, since in other types of civil procedure, it is only possible to be fully reimbursed for procedural costs. Any additional costs such as lawyer fees are reimbursed only in exceptional cases. ${ }^{26}$ Generally, litigation costs are calculated according to a point-based system (liquidatietarief) which allocates values to certain acts and phases in judicial proceedings. The costs are then granted based on the level of success of either party's claims and, in exceptional cases, on the judge's assessment of whether granting the claimed costs would be reasonable. Sometimes the courts deem the costs claimed too high. In those cases, the court will lower the cost claim to a standard it considers to be more reasonable.

Consequently, the reimbursement granted is often not even close to the actual litigation costs incurred by parties. ${ }^{27}$ While this system is not legally binding upon courts, it constitutes

\footnotetext{
22 These Articles entail a 'General obligation', an elaboration on which 'Persons [are] entitled to apply for measures, procedures and remedies', and the possibility to provide for 'Alternative measures'.

${ }^{23}$ Staatsblad 2007, No. 108; G. Cumming, M. Freudenthal and R. Janal, Enforcement of Intellectual Property Rights in Dutch, English and German Civil Courts (Kluwer Law International, Alphen aan den Rijn 2008) p. 101. C. Gielen, 'De Richtlijn Handhaving IE-Rechten' (2005) NTER, p. 8; C. Gielen, 'De Richtlijn Handhaving IERechten' (2005) NTER, pp. 6-11; Title 15 of the Third Book of the Dutch Code of Civil Procedure applies exclusively to intellectual property procedures.

${ }^{24}$ C. Gielen, 'De Richtlijn Handhaving IE-Rechten' (2005) NTER, p. 8; C. Gielen, 'De Richtlijn Handhaving IERechten' (2005) NTER, pp. 6-11.

${ }^{25}$ Article 14 Enforcement Directive; see for example F.W. Grosheide, Monografieën BW: Intellectuele Eigendom (A32 edn Kluwer Deventer 2011), p. 60, 57; P.G.F.A. Geerts, Bescherming van de Intellectuele Eigendom, $\left(10^{\text {th }}\right.$ edn Kluwer 2013), p. 10; N. van der Laan, 'Het Toepassingsbereik van de Handhavingsrichtlijn en de Uitvoeringswet' (2007) IER 96, p. 1.

${ }^{26}$ Hof 's-Gravenhage 25 september 2002, NJ 2003/128 (Court of Appeal in the Netherlands)

27 P.G.F.A. Geerts, Bescherming van de Intellectuele Eigendom, (10 th edn Kluwer 2013), p. 11; G. Cumming, M. Freudenthal and R. Janal, Enforcement of Intellectual Property Rights in Dutch, English and German Civil Courts (Kluwer Law International, Alphen aan den Rijn 2008) p. 126; see, for example, Hof 's-Gravenhage, 25 September 2002, NJ 2003/128 and HR 17 December 2004 para. 3.5, NJ 2005/361.
} 
a common practice. Among other things, it allows moderation of the litigation costs claimed against innocent intermediaries. As will be shown, the Dutch courts oblige them to compensate the right holders, but not in full. They argue that this would be unfair since the unsuccessful party was not itself an infringer. ${ }^{28}$

Another fact worth pointing out is that the corrective measures mentioned in Article 10 of the Enforcement Directive were already part of the Dutch enforcement scheme. The measure of recalling goods in the Enforcement Directive was actually inspired by a judge-made Dutch doctrine..$^{29}$ This doctrine was codified in Article 28 of the Dutch Copyright Act. ${ }^{30}$ Under the now existing practice in the copyright area, the following strategy was devised. In addition to the recall of goods, the infringer could be ordered to write a letter to its business clients to inform them about the judgment and warn them about possible follow-on enforcement actions against them when they choose not to return the infringing goods in question. In most cases, the business clients are offered reimbursement for the sales and cost of transport for adhering to the order. ${ }^{31}$ The consumer is still protected because the goods cannot be recalled from private individuals who purchased them for private use only. ${ }^{32}$ Today, the corresponding paragraph of Article 28 of the Dutch Copyright Act is a result of the implementation of the Enforcement Directive in 2007. It allows the court to order the infringer to bear the costs of the recall. ${ }^{33}$ However, prior to the Directive, Dutch law prescribed that the recall of goods was to be paid for by the rightholders. ${ }^{34}$

As regards the right to information, Article 28 of the Dutch Copyright Act implements Article 8 of the Enforcement Directive. ${ }^{35}$ It provides for the conditions under which it is

C. Gielen, 'De Richtlijn Handhaving IE-Rechten' (2005) NTER, p. 10.

${ }^{28} \mathrm{Rb}$. 's-Gravenhage, 5 January 2007, IER 2007, 22 (Court of First Instance in the Netherlands, interlocutory proceedings); Rb. 's-Gravenhage 10 May 2012, LJN BW5387, paras. 4.44 (Court of First Instance in the Netherlands). However, it is important to understand that there are no precedents in Dutch litigation. This means that even though there are cases pointing in this direction, it may still fail to develop as a general rule.

${ }^{29}$ HR 23 February 1990 ECLI:NL:HR:1990:AD1044 (Hameco case)

${ }^{30}$ Auteurswet 1912; HR 23 February 1990, NJ 1990, 664 (Supreme Court of The Netherlands); COM/2003/0046 Final - COD 2003/0024, p. 22; G. Cumming, M. Freudenthal and R. Janal, Enforcement of Intellectual Property Rights in Dutch, English and German Civil Courts (Kluwer Law International, Alphen aan den Rijn 2008) p. 94 and 122; C. Gielen, 'De Richtlijn Handhaving IE-Rechten' (2005) NTER, p. 9.

${ }^{31}$ C. Gielen, 'De Richtlijn Handhaving IE-Rechten' (2005) NTER, p. 9; G. Cumming, M. Freudenthal and R. Janal, Enforcement of Intellectual Property Rights in Dutch, English and German Civil Courts (Kluwer Law International, Alphen aan den Rijn 2008) p. 122.

32 Auteurswet 1912; P.G.F.A. Geerts, Bescherming van de Intellectuele Eigendom, (10 th edn Kluwer 2013), p. 82.

33 Staatsblad 2007, no. 108; N. van der Laan, 'Het Toepassingsbereik van de Handhavingsrichtlijn en de Uitvoeringswet' (2007) IER 96, p. 2.

${ }^{34}$ E.g. old Article 28(5) of the Dutch Copyright Act; G. Cumming, M. Freudenthal and R. Janal, Enforcement of Intellectual Property Rights in Dutch, English and German Civil Courts (Kluwer Law International, Alphen aan den Rijn 2008) p. 123.

${ }^{35}$ G. Cumming, M. Freudenthal and R. Janal, Enforcement of Intellectual Property Rights in Dutch, English and German Civil Courts (Kluwer Law International, Alphen aan den Rijn 2008) p. 114. 
possible for the rightholder to obtain information from both the (alleged) infringer and a third party involved in the infringement in the ways specified in Article 8(1) of the Enforcement Directive. In addition, a general rule was introduced in Article 1019f of the Dutch Code of Civil Procedure ${ }^{36}$ to complement the existing rights-specific provisions regarding right to information. Previously, the Act only contained a provision on hearing witnesses. ${ }^{37}$ In the wording, no distinction between the type of third parties is attempted. In 2005, the Supreme Court of the Netherlands ruled in Lycos Pessers judgement that it should not be necessary to obtain an interlocutory judgment only in order to receive information from Internet service providers. ${ }^{38}$ Depending on the circumstances, the refusal to deliver certain kinds of information to rightholders might even be unlawful. ${ }^{39}$ Following the decision, it has become standard practice in the Netherlands that intermediaries are ordered to provide identifying details to rightsholders on this basis, rather than based on the article 28 of the Dutch Copyright Act.

Finally, the Dutch law implemented an explicit legal basis in the separate intellectual property acts for injunctions against intermediaries by the amendment of March 2007. The third sentence of Article 11 of the Enforcement Directive was implemented into all separate acts on intellectual property rights, ${ }^{40}$ such as Article 2(5) of the Database Act, Article 17(2) of the Act on Original Topographies of Semiconductor products, Article 70(2) of the Seeds and Planting Materials Act 2005 and in Article 13a(2) of the Agricultural Quality Act. ${ }^{41}$ It also introduced Article 26d of the Dutch Copyright Act and Article 15e of the Neighbouring Rights $\mathrm{Act}^{42}$. No such provision was implemented into the Dutch Tradename Act. While the articles across IP statues are adjusted for particular rights, the formulation used is essentially the same, namely that 'The court can at the request of the maker [order] ... intermediaries [,] whose services are being used by third parties to infringe copyright, [to suspend] those services used to make that infringement (..)'.

This way of cross-IP implementation still causes some confusion. Since the 2004 amendment, implementing the InfoSoc Directive, did not introduce any changes, the 2007 amendment, the Enforcement Directive amendment, had to take upon this role. Article $8(3)$

\footnotetext{
${ }^{36}$ Article 1019f of the Dutch Code of Civil Procedure contains the right of information.

${ }^{37}$ G. Cumming, M. Freudenthal and R. Janal, Enforcement of Intellectual Property Rights in Dutch, English and German Civil Courts (Kluwer Law International, Alphen aan den Rijn 2008) pp. 115-116.

38 HR 25 November 2005, LJN AU4019.

39 Ibid.

40 Kamerstukken II, 2005-2006, 30 392, no. 6, p. 7.

41 Databankenwet, Wet houdende regelen inzake de bescherming van oorspronkelijke topografieën van halfgeleiderprodukten, Zaaizaad- en plantgoedwet 2005 and the Landbouwkwaliteitswet.

42 'Wet op de Naburige Rechten'; This Act is the implementation of the Rome Convention 1961 and Geneva Convention 1971.
} 
was at first only thought to be implemented in the provisions regarding the liability of service providers found in the Dutch Civil Code. ${ }^{43}$ In addition, no reference was made to the InfoSoc Directive in the parliamentary documents accompanying the 2007 amendment. ${ }^{44}$ This also seems to lead to confusion in both case law and literature. When discussing Articles $26 \mathrm{~d}$ of the Dutch Copyright Act and 15e of the Neighbouring Rights Act, both Dutch courts and legal scholars often refer both to Article 8(3) of the InfoSoc Directive and the third sentence of Article 11 of the Enforcement Directive, owing to the Dutch implementation history. ${ }^{45}$ While both Articles aim to achieve the same objective, as recently put by Advocate General Szpunar, the copyright-specific provision should take precedence in case of matters covered by the InfoSoc Directive. ${ }^{46}$

\section{Dutch Website Blocking Practice}

BREIN is a very active Dutch anti-piracy agency. ${ }^{47}$ It has been bringing proceedings against intermediaries to shut down host-service websites for some time now. ${ }^{48}$ And it has been very successful in this effort. For example, as early as 2007, BREIN forced Leaseweb, a web-hosting provider, to block the website Everlasting, which used a BitTorrent-system. The Court of First Instance found in the interlocutory proceedings that the operator had acted unlawfully by wilfully facilitating the infringement of copyright and related rights via his website. ${ }^{49}$ Leaseweb had appealed, but the Court of Appeal confirmed it. ${ }^{50}$

However, website blocking injunctions against intermediaries did not come about as easily in a recent legal dispute between BREIN and two Internet access providers, Ziggo and XS4ALL. Some legal questions even had to be referred to the Court of Justice of the European Union by the Dutch Supreme Court. ${ }^{51}$ What is behind this dispute?

\footnotetext{
43 P.G.F.A. Geerts, Bescherming van de Intellectuele Eigendom, (10 ${ }^{\text {th }}$ edn Kluwer 2013) p. 55; Article 6:196c(5) of the Dutch Civil Code ('Burgerlijk Wetboek') reads: "The above mentioned paragraphs do not affect the possibility to get a court order to terminate or prevent an infringement or an injunction for the removal or disabling of access to information." This provision corresponds to the carve-outs from the safe harbours in the E-Commerce Directive, which, however, don't confer any jurisdiction to grant injunctions but only pierce the immunities with a possibility of the injunctive relief - see M. Husovec, Holey cap! CJEU drills (yet) another hole in the eCommerce Directive's safe harbours (2017) 12 (2) Journal of Intellectual Property Law \& Practice, 115

${ }^{44}$ Kamerstukken II, 2005-2006, 30 392, no. 6, p. 7.

45 E.J. Numann, C.A. Streefkerk, A.H.T. Heisterkamp, G. Snijders, M.V. Polak; G.R.B. van Peursem, '2064' (2015) NJ 41, p. 2887.

46 Case C-610/15 Stichting BREIN v Ziggo BV and XS4ALL BV, Opinion of AG Szpunar, para. 56.

47 'Wat is BREIN?' <http://stichtingbrein.nl/wat-is-brein.php > accessed on 7 February 2016.

48 E.g. Rb. Amsterdam 21 June 2007, LJN BA7810 (Court is First Instance in the Netherlands).

${ }^{49} \mathrm{Rb}$. Amsterdam 21 June 2007, LJN BA7810 (Court is First Instance in the Netherlands).

${ }^{50}$ Hof Amsterdam 3 July 2008, LJN BD6223 (Court of Appeal in the Netherlands).

${ }^{51}$ HR 13 November 2015, ECLI:NL:HR:2015:3307, paras. 4.2 and 4.4.2 (Supreme Court of The Netherlands).
} 
BREIN is a foundation with full legal capacity governed by Dutch law which has the objective to protect and enforce both copyrights and neighbouring rights by means of what is essentially a 'joint anti-piracy program'. ${ }^{2}$ Based on Article 3:305a(1) of the Dutch Civil Code, ${ }^{53}$ BREIN can bring proceedings to protect similar interests as those laid down in its statute, including, but not limited to music, films, books, games, and even interactive software. For the pursuit of its objective, the statute of BREIN even allow this foundation to bring proceedings to obtain damages on its own title. ${ }^{54}$ This broad, general mandate has been accepted in case law, which in practice means that proceedings brought by BREIN are hardly ever dismissed. ${ }^{55}$ BREIN represents diverse organizations, including Buma-Stemra, a Dutch collecting society for the rights of music authors and publishers, the Motion Pictures Association of America, SENA, an association of musical performing artists, NUV, a book publishers association. ${ }^{56}$ It thus represent not only major studios, but also independent authors. BREIN holds a very powerful position in the Netherlands since it represents the vast majority of rightholders in the field of copyright and related rights in the Netherlands. ${ }^{57}$ The set-up allows them, among other things, to out-source and scale-up any legal efforts.

This unique position of BREIN gives a chance to litigate many cases and thus build a coherent litigation strategy. BREIN's focus is primarily on commercial-scale infringers and doesn't enforce against end-users. One of the typical targets of its efforts is The Pirate Bay, the BitTorrent-index website that BREIN is trying to get blocked by two local access providers, Ziggo and XS4ALL. ${ }^{58}$ The Pirate Bay is known to be a platform used by private individuals (peer-to-peer) mostly to share protected works illegally, and has been a party to and object of numerous proceedings. ${ }^{59}$

\footnotetext{
52 'The BREIN Foundation' <http://stichtingbrein.nl/english.php> accessed 10 February 2017.

53 Burgerlijk Wetboek.

54 Articles 3.1 and 3.2(c) and (f) of BREIN's Statute.

55 See, for example, Rb. Amsterdam 21 June 2007, LJN BA7810 (Court is First Instance in the Netherlands).

56 'The BREIN participants' < http://stichtingbrein.nl/english.php> accessed 23 February 2017.

${ }^{57}$ Hof Den Haag January 28, 2014, ECLI:NL:GHDHA:2014:88, para. 1.d (Court of Appeal in the Netherlands).

58 P.H. Blok, R. Kalden en M.P.M. Loos, 'Nr. 13 Brein/Ziggo \& XS4ALL' (2012) AMI 3, para. 2.3.

59 E.J. Numann, C.A. Streefkerk, A.H.T. Heisterkamp, G. Snijders, M.V. Polak; G.R.B. van Peursem, '2064' (2015) NJ 41, p. 2886; P.H. Blok, R. Kalden en M.P.M. Loos, 'Nr. 13 Brein/Ziggo \& XS4ALL' (2012) AMI 3, paras. 2.9-2.10, 2.14-2.16; 'Providers moeten Pirate Bay blokkeren' (2012) NJB 236.
} 
The general legal framework for intermediary immunities which implements the E-Commerce Directive is set in Article 6:196c of the Dutch Civil Code. ${ }^{60}$ The separate legal acts contain a legal basis for injunctions against intermediaries since the amendment in 2007. The website blocking cases discussed in this article revolve mainly around Article 26d of the Dutch Copyright Act and Article 15e of the Neighbouring Rights Act. As explained earlier, the precondition of this provision is, in line with the Union 'template', that the services of an intermediary are being used by a third party to infringe. However, that depends on answering of the question whether the website to be blocked can be considered an infringer itself. ${ }^{61}$ If the website would not be an infringer, be it primary or secondary, then, in theory, the users could be still 'third party' in sense of Art 8(3) InfoSoc and Art 11 of the Enforcement Directive. However, if the user's wrongdoing, not the website's is a trigger for injunctions, then it is questionable whether blocking of such non-infringing website should be permissible. Not necessarily as a matter of wording of these provisions, which are admittedly very broad, ${ }^{62}$ but of the website operator's freedom of expression.

The Court of First Instance ${ }^{63}$ did not elaborate on this problem. It just limited itself to the qualification that the qualification of the subscribers of the two access providers, who uploaded illegal works to the BitTorrent system, are the infringers. ${ }^{64}$ Furthermore, the court decided the balancing of the rights to information and freedom of expression against the copyright and related rights in favour of the latter. One of the Court's considerations hereto was the fact that 90 to $95 \%$ of the material available via The Pirate Bay constitutes illegal content. ${ }^{65}$ Moreover, it concluded that the argument that such a blocking measure was

\footnotetext{
${ }^{60}$ Article 6:196c(5) Burgerlijk Wetboek ('The above mentioned paragraphs do not affect the possibility to get a court order to terminate or prevent an infringement or an injunction for the removal or disabling of access to information.')

61 E.J. Numann, C.A. Streefkerk, A.H.T. Heisterkamp, G. Snijders, M.V. Polak; G.R.B. van Peursem, '2064' (2015) NJ 41, p. 2887; 'Conclusie AG bij Europees Hof: blokkering toegestaan indien p2p-site inbreuk maakt of onrechtmatig handelt' (9 February 2017) <http://stichtingbrein.nl/nieuws.php?id=441> accessed 10 February 2017; E.J. Numann, C.A. Streefkerk, A.H.T. Heisterkamp, G. Snijders, M.V. Polak; G.R.B. van Peursem, '2064' (2015) NJ 41, pp. 2887-2888.

62 Similar Christina Angelopoulos, 'AG Szpunar in Stichting Brein v Ziggo: An Indirect Harmonisation of Indirect Liability’ (Kluwer Copyright Blog, 2017) available at < http://kluwercopyrightblog.com/2017/03/23/ag-szpunarstichting-brein-v-ziggo-indirect-harmonisation-indirect-liability/>

63 Rb. 's-Gravenhage 11 January 2012, ECLI:NL:RBSGR:2012:BV0549 (Court of First Instance in the Netherlands).

${ }^{64}$ Article 16c of the Dutch Copyright Act on electronic copies for private use prohibits the uploading of such copies via the Internet since that is found to constitute a communication to the public within the meaning of Article 12 Dutch Copyright Act. The Internet is not specifically included in this Article, but the list is non-exhaustive. See, for example, P.G.F.A. Geerts, Bescherming van de Intellectuele Eigendom, (10 ${ }^{\text {th }}$ edn Kluwer 2013), pp. 7475; 'Providers moeten Pirate Bay blokkeren' (2012) NJB 236.

65 P.H. Blok, R. Kalden en M.P.M. Loos, 'Nr. 13 Brein/Ziggo \& XS4ALL' (2012) AMI 3, paras. 4.25, 4.27 and 4.28; 'Providers moeten Pirate Bay blokkeren' (2012) NJB 236.
} 
disproportional due to its limited effectiveness is not convincing. The mere fact that some users can circumvent a technical measure is by itself insufficient to find it disproportional. ${ }^{66}$ The CJEU's preliminary ruling in UPC Telekabel Wien ${ }^{67}$ was only about to be delivered.

The access providers also argued that the proposed measures are incompatible with the prohibition of general monitoring enshrined in Article 15(1) of the E-Commerce Directive. ${ }^{68}$ However, the court found that the blocking order does not constitute an active monitoring obligation because only the IP-addresses and domain names and their (sub)domains need to be checked, not the content of the information sent. According to the court, the order in question differs from the filtering system in Scarlet Extended.$^{69}$ Moreover, BREIN promised to conduct the search for new or additional IP-addresses and (sub)domain names on its own. The court accepted this, however, limiting the order to one specific website - The Pirate Bay. ${ }^{70}$ In the actual ruling, the court spells out this obligation as follows:

“(..) Ziggo and XS4ALL [are obliged], within ten days after its judgment was officially notified to the unsuccessful party by the bailiff, to stop and keep from providing (...) [their] services used for infringing the copyrights and related rights of the rightholders whose interests are represented by BREIN, by means of blocking, and keeping blocked, the access of their subscribers to the domain names/(sub)domain names and IPaddresses through which The Pirate Bay operates."71

This was followed by a list of IP-addresses and (sub)domain names. In addition, the Court also ordered the access providers 'to block and keep blocked the access to new/additional IPaddresses and/or domain names/(sub)domain names through which The Pirate Bay would start operating, within ten days after report by BREIN, by means of fax or registered letter, to Ziggo and XS4ALL of the correct IP-addresses and/or domain names/(sub)domain names'. ${ }^{72}$

\footnotetext{
66 Rb. 's-Gravenhage 11 January 2012, ECLI:NL:RBSGR:2012:BV0549, para. 4.35 (Court of First Instance in the Netherlands).

${ }^{67}$ Case C-314/12 UPC Telekabel Wien (ECJ 27 March 2014), paras. 56-57.

${ }^{68}$ Directive 2000/31/EC of the European Parliament and of the Council of 8 June 2000 on certain legal aspects of information society services, in particular electronic commerce, in the Internal Market (OJ L 178/1).

69 Case C-70/10 Scarlet Extended [2011] ECR I-11959; Rb. 's-Gravenhage 11 January 2012, ECLI:NL:RBSGR:2012:BV0549, para. 4.46 (Court of First Instance in the Netherlands).

${ }^{70}$ Rb. 's-Gravenhage 11 January 2012, ECLI:NL:RBSGR:2012:BV0549, para. 4.46 (Court of First Instance in the Netherlands).

71 Translation by one of the authors; P.H. Blok, R. Kalden en M.P.M. Loos, 'Nr. 13 Brein/Ziggo \& XS4ALL' (2012) AMI 3, paras. 4.34-4.35, 4.55-4.57, and 5.3-5.7; Rb. 's-Gravenhage 11 January 2012, ECLI:NL:RBSGR:2012:BV0549, para. 5.3 (Court of First Instance in the Netherlands).

72 Translation by one of the authors; Rb. 's-Gravenhage 11 January 2012, ECLI:NL:RBSGR:2012:BV0549, para. 5.4 (Court of First Instance in the Netherlands).
} 
As an incentive for compliance, a penalty was set by the Court per event of noncompliance, with an increase per day for which the infringement would continue. ${ }^{73}$ When the entire a particular penalty ceiling would be reached, BREIN could go back to the Court to obtain a new, more stringent court order. Obviously, non-complaint parties act unlawfully when ignoring court orders, for which they would become directly liable themselves.

The Court of First Instance based the order for ex-post submission of IP-addresses and (sub)domain names on CJEU's L'Oréal v eBay, which allowed for the possibility to order intermediaries to undertake measures to prevent future infringements. ${ }^{74}$ Scarlet Extended ${ }^{75}$ was also cited, but the Court found that the measure struck a fair balance. ${ }^{76}$ No additional intervention by judiciaries necessary for further upgrades because the order is granted following the main fair and impartial procedure. The court argued that it would render Article 8(3) of the InfoSoc Directive and the third sentence of Article 11 of the Enforcement Directive meaningless if such orders could not be upgraded after the grant. ${ }^{77}$ The court did not mention any specific technologies that needed to be deployed, nor of any obligations to invest in new technologies.

In many domestic cases, as in this one, the rightholders request the compensation of their litigation costs. While the Court of First Instance considered requirement of the 'full compensation' set in Article 1019h of the Dutch Code of Civil Procedure ${ }^{78}$ to be applicable in this case, it found that awarding such compensation would be unfair. It was pointed out that access providers are not infringers themselves, ${ }^{79}$ and they have the right to defend their own and subscriber's rights. As a consequence, contrary to usual allocation, they did not have entirely to compensate BREIN.

\footnotetext{
${ }^{73}$ Rb. 's-Gravenhage 11 January 2012, ECLI:NL:RBSGR:2012:BV0549, para. 5.5 (Court of First Instance in the Netherlands).

${ }^{74}$ Rb. 's-Gravenhage 11 January 2012, ECLI:NL:RBSGR:2012:BV0549, para. 4.18 (Court of First Instance in the Netherlands).

75 Case C-70/10 Scarlet Extended [2011] ECR I-11959.

76 Rb. 's-Gravenhage 11 January 2012, ECLI:NL:RBSGR:2012:BV0549, para. 4.19 (Court of First Instance in the Netherlands).

77 Rb. 's-Gravenhage 11 January 2012, ECLI:NL:RBSGR:2012:BV0549, para. 4.42 (Court of First Instance in the Netherlands).

78 Wetboek van Burgerlijke Rechtsvordering.

79 Rb. 's-Gravenhage, 5 January 2007, IER 2007, 22 (Court of First Instance in the Netherlands, interlocutory proceedings); Rb. 's-Gravenhage 10 May 2012, LJN BW5387, paras. 4.44 (Court of First Instance in the Netherlands).
} 
BREIN has also been successful in a number of other similar cases, despite the turn of events in the appeal stage of this case. Just after the judgment was delivered by the Court of First Instance in BREIN vs Ziggo and XS4ALL in 2012, BREIN started an interlocutory procedure against five other Dutch access providers to block The Pirate Bay website. Interestingly, in this case, this court considered that it would need to largely follow the reasoning in the above cases since the cases were so similar in nature. ${ }^{80}$ While the court reiterates the earlier case-law as saying that the operators of The Pirate Bay are not copyright infringers, it also notes that they are nevertheless acting unlawfully by facilitating infringements of subscribers. Very likely, though, the intended distinction was one between copyright infringement and general tort residing in facilitation of the user's wrongdoing. The court did not, however, further elaborate on this point. The blocking order requested by BREIN for the (sub)domains and IP-addresses was granted for those mentioned in the claim, together with a penalty for every day of noncompliance coupled with a penalty ceiling. ${ }^{81}$ However, the extension of this blocking order to future submissions of (sub)domains and IP-addresses was denied. ${ }^{82}$ Shortly after this judgment, the Court of Appeals came to a very different result in BREIN $v$ Ziggo and XS4ALL, which forced BREIN to put the cases against other providers aside.

The Court of Appeal first identified the uploading subscribers as 'third parties', followed by the comment that their services were used by this group of subscribers to infringe copyrights and neighbouring rights. ${ }^{83}$ It then ruled out both that The Pirate Bay communicated protected works to the public within the meaning of Article 3 of the InfoSoc Directive, and that it engaged in an intervention of such a communication. ${ }^{84}$ The Court of Appeal concluded by stating that Article 8(3) of the InfoSoc Directive and the third sentence of Article 11 of the Enforcement Directive are not applicable to situations in which the services of intermediaries are used by a third party to merely facilitate or stimulate infringement by others. ${ }^{85}$ Although Dutch law could theoretically construe potential liability as a tortfeasor on the basis of general tort law (see below), it seems that the court assumed that such a wrongdoer would not qualify as an 'infringer' in the sense of Union law.

\footnotetext{
${ }^{80} \mathrm{Rb}$. 's-Gravenhage 10 May 2012, LJN BW5387, paras. 4.3-4.4 (Court of First Instance in the Netherlands).

81 Rb. 's-Gravenhage 10 May 2012, LJN BW5387, paras. 4.41-4.42, 5.1 and 5.5 (Court of First Instance in the Netherlands).

82 Rb. 's-Gravenhage 10 May 2012, LJN BW5387, paras. 4.42 and 5.5 (Court of First Instance in the Netherlands).

${ }^{83}$ Hof Den Haag January 28, 2014, ECLI:NL:GHDHA:2014:88, para. 4.4 (Court of Appeal in the Netherlands).

${ }^{84}$ Case C-432/09 Airfield and Case C-135/10 Marco del Corso as cited in Hof Den Haag January 28, 2014, ECLI:NL:GHDHA:2014:88, para. 4.6 (Court of Appeal in the Netherlands).

${ }^{85}$ Hof Den Haag January 28, 2014, ECLI:NL:GHDHA:2014:88, para. 4.8 (Court of Appeal in the Netherlands).
} 
Another interesting and probably more controversial aspect of the reasoning of this court was the manner in which it interpreted the conditions stemming from Article 52 of the Charter of Fundamental Rights of the EU. ${ }^{86}$ The Dutch Court of Appeals found the blocking order to be ineffective due to evidence of large-scale technical circumvention and availability of such protected works via alternative websites. The submitted evidence included a report on the daily volume of the Internet, Network and BitTorrent traffics for the period of the three months before and three months after the blocking order was implemented. The report showed no noticeable change in BitTorrent traffic. In contrast, a consumer survey was submitted by BREIN which showed a clear decline in the number of infringers after the blocking order was implemented. The court then interpreted the effectiveness test to mean that the measures had to be effective in terms of the actual reduction of the overall number of infringements. The reduction of the number of infringers did not matter, according to the court. It was thus implied that the effectiveness should be understood in terms of aggregate efficacy, regardless of whose rights continue to be infringed. Against these requirements, the blocking order was found to be a disproportional and unjustified interference with the rights of the Internet service providers, irrespective of its low implementation costs. ${ }^{87}$

The same type of evidence and arguments were presented also before the Court of First Instance in the case BREIN brought against five other Dutch Internet service providers. ${ }^{88}$ Interestingly, it led to different outcome. This court opined that the blocking measure by itself may be ineffective in order to reduce the number of infringements, but found that the effectiveness of the package of measures undertaken by BREIN should be assessed as a whole. The court argued that due to the existing technologies to circumvent blocking measures, other measures such as taking down proxies are imperative for the effectiveness of BREIN's fight against infringements. It found that the evidence submitted clearly showed that the blocking measures were just one element of the overall strategy of BREIN in the enforcement of copyrights and related rights. ${ }^{89}$

The website blocking saga is not yet finished. The Dutch Supreme Court found that the Court of Appeal had erred in law by considering the blocking order to be ineffective on the merits. In its view, the lower court erred by finding that the effectiveness means prevention of the overall number of infringements. Even measures that do not lead to a complete stop of

${ }^{86}$ Hof Den Haag January 28, 2014, ECLI:NL:GHDHA:2014:88, paras. 5.3-5.6 (Court of Appeal in the Netherlands).

${ }^{87}$ Hof Den Haag January 28, 2014, ECLI:NL:GHDHA:2014:88, para. 5.22 (Court of Appeal in the Netherlands).

${ }^{88} \mathrm{Rb}$. 's-Gravenhage 10 May 2012, LJN BW5387, paras. 4.18-4.19 (Court of First Instance in the Netherlands).

${ }^{89}$ Ibid. 
infringements can be still compatible with the proportionality requirement of Article 52(1) EU Charter. On the other hand, it is not entirely clear whether, in its view, Union law dictates that such an injunction always complies with the low UPC-standard, namely that it makes the infringements more difficult or severely discourages them..$^{90}$ However, the Court observes, as was argued by the parties, that neither EU law nor Dutch law requires that such an order could only be granted if all other relevant BitTorrent websites would also be part of the proceedings. ${ }^{91}$ Thus the court finds the step-by-step approach taken by BREIN in fighting copyright infringements to be compatible with the proportionality requirement of Article 52(1) EU Charter. ${ }^{92}$ This could potentially be seen as acknowledgment of the fact that other levels of effectiveness are possible, but that the domestic law just did not require them.

In addition, the Supreme Court considered a different question of Union law to be open. If a website to be blocked is an 'infringing third party' that uses access provider's services in the sense of Article 8(3) of the InfoSoc Directive, then it has to 'infringe' copyright. Dutch law does not recognize any copyright specific secondary liability doctrine, ${ }^{93}$ and liability of other than direct infringers is usually considered under general tort law. However, provided that The Pirate Bay is not a direct infringer, is such a domestically defined tortfeasor also an 'infringer' in sense of the Union law? For these reasons, the Supreme Court decided to stay the proceedings and request the CJEU for a preliminary ruling. ${ }^{94}$ Its first question essentially asks whether operators of websites such as The Pirate Bay itself communicate protected works to the public within the meaning of Article 3(1) of the InfoSoc Directive. ${ }^{95}$ The phrasing of the second questions is, however, curious. In case the answer to the first question is not affirmative, the Supreme Court asks the following: 'Do Article 8(3) of the [InfoSoc] Directive and Article 11 of the Enforcement Directive offer any scope for obtaining an injunction against an intermediary as referred to in those provisions, if that intermediary facilitates the infringing acts of third parties' with a system that indexes and categorises metadata on protected works? ${ }^{96}$

\footnotetext{
${ }^{90}$ HR 13 November 2015, ECLI:NL:HR:2015:3307, paras. 4.2 and 4.4.2 (Supreme Court of The Netherlands); Case C-610/15 Stichting BREIN v Ziggo BV and XS4ALL BV, Opinion of AG Szpunar, paras. 80-82.

${ }^{91}$ HR 13 November 2015, ECLI:NL:HR:2015:3307, para 4.4.2.

92 HR 13 November 2015, ECLI:NL:HR:2015:3307, para 4.4.3.

93 M. de Cock Buning and D. van Eek, 'Aansprakelijkheid van derden bij auteursrechtinbreuk' (2009) IER 5 2267 (the liability of different service providers in the information society in copyright is based on tort and implemented into Article 6:196c Dutch Civil Code (BW) based on Articles 12-14 of the e-Commerce Directive). ${ }^{94}$ HR 13 November 2015, ECLI:NL:HR:2015:3307, paras. 5.5-5.9 (Supreme Court of The Netherlands).

95 The first question: "Is there a communication to the public within the meaning of Article 3(1) of the ... [InfoSoc] Directive by the operator of a website, if no protected works are available on that website, but a system exist ... by means of which metadata on protected works which is present on the users' computers is indexed and categorised for users, so that the users can trace and upload and download the protected works on the basis thereof?" Case C-610/15 Stichting BREIN v Ziggo BV and XS4ALL BV.

96 Case C-610/15 Stichting BREIN v Ziggo BV and XS4ALL BV.
} 
It is not clear whether the court asks this question on the premise that such facilitation constitutes a tort under the domestic law, or even if such facilitation is entirely innocent.

The CJEU has not yet decided, but on 8 February 2017, Advocate General Szpunar delivered his opinion. He found that the first question should be answered in the affirmative, arguing that the users are the actors communicating to the public within the meaning of Article 3(1) of the InfoSoc Directive, but concluding that The Pirate Bay is also a necessary element for the users' infringements. The refusal to rectify the situation by such an operator of a BitTorrent-index website when infringements via its website are brought to his/her attention 'may be regarded as (...) intended to allow, expressly, the continuation of the illegal making available of that work and, hence, as an intentional action. ${ }^{97}$ This steps seems to move beyond the hyperlinking case-law, by recognizing an intentional co-intervention as a type of infringement. Whether this is an actual extension of a communication to the public right, or rather a concealed development of a Union-specific secondary liability doctrine is a question that will need to be studied in the future.

However, if the first question would be answered in the negative, the Advocate General argued that indirect liability is not harmonised at the EU level, but could nevertheless be possible when domestic law provides for such liability. Article 14(1) of the E-Commerce Directive does not provide protection to the website in this case, since The Pirate Bay knows illegal content is being shared via its website, but does nothing to stop it, which means it could become indirectly liable for the infringing content and activities. ${ }^{98}$ Furthermore, when applying the conditions established in UPC Telekabel Wien, and considering the proportion of illegal content and the behaviour of the operators, it seems rather likely that a blocking order against the website of The Pirate Bay would be proportional. ${ }^{99}$ Moreover, in addition, the Advocate General argues that:

"[if] a measure that is less restrictive for service providers and constitutes less of an intrusion upon the rights of users were now rejected on the ground that it is not sufficiently effective, internet service providers would ultimately be released de facto from their duty to cooperate in the fight against copyright infringement." 100

\footnotetext{
97 Case C-610/15 Stichting BREIN v Ziggo BV and XS4ALL BV [2017] Opinion of AG Szpunar, paras 54, 48-51.

${ }^{98}$ Case C-610/15 Stichting BREIN v Ziggo BV and XS4ALL BV, Opinion of AG Szpunar, paras 65-68.

99 Case C-610/15 Stichting BREIN v Ziggo BV and XS4ALL BV, Opinion of AG Szpunar, paras 71 and 76.

100 Case C-610/15 Stichting BREIN v Ziggo BV and XS4ALL BV, Opinion of AG Szpunar, para 83.
} 
The Advocate General seems to reject that a user's infringing behaviour alone could constitute a basis for injunctions against intermediaries. ${ }^{101}$ The CJEU does not always follow the Advocate General's Opinion. This is especially the case in the latest Internet case-law where the rate of disagreement seems higher than usual. In any case, however, there are only two options for the Court. Either the CJEU extends the communication to the public case-law to cover also situations of co-intervention - something that the English courts are already doing, ${ }^{102}$ or it leaves the scope to be defined on the national level, by referring the domestic court to a potential secondary liability doctrine. Given the choice, and the Court's harmonizing agenda, ${ }^{103}$ it is hard to imagine that the answer would not be in line with the first option.

However, since the CJEU cannot solve all the future cases through such a solution, it is already clear that the reference to domestic laws will continue to build part of its answers. There is also a third option, namely that blocking of innocent websites will be also allowed provided that users infringe rights - but remain limited only through fundamental rights exercise. ${ }^{104}$ Consequently, for them, the website blocking injunction would be available depending on whether the domestic secondary liability doctrines, if available, consider such players infringers or not. If such doctrine is available on the national level, even if construed as a general tortious liability, however, the CJEU could mandate its use through interpretation of the term 'to infringe' in Article 8(3) of the InfoSoc Directive and Article 11, third sentence, of the Enforcement Directive.

101 Case C-610/15 Stichting BREIN v Ziggo BV and XS4ALL BV, Opinion of AG Szpunar, para. 64 ("The circumstances envisaged in Article 8(3) of Directive 2001/29 presuppose the existence of a link between the subject of the injunction and the copyright infringement. A measure blocking a website implies that it has been established that the operator of that site has been held liable for copyright infringement using the services of the intermediary to which the injunction is addressed."); For criticism - see Christina Angelopoulos, 'AG Szpunar in Stichting Brein v Ziggo: An Indirect Harmonisation of Indirect Liability’ (Kluwer Copyright Blog, 2017) available at < http://kluwercopyrightblog.com/2017/03/23/ag-szpunar-stichting-brein-v-ziggo-indirectharmonisation-indirect-liability/>

${ }^{102}$ Twentieth Century Fox Film Corp v Newzbin Ltd [2010] EWHC 608 (Ch), [2010] FSR 21 at [125] ("This service is not remotely passive. Nor does it simply provide a link to a film of interest which is made available by a third party. To the contrary, the defendant has intervened in a highly material way to make the claimants' films available to a new audience, that is to say its premium members."); The Football Association Premier League Ltd v British Sky Broadcasting Ltd \& Ors [2013] EWHC 2058 (Ch) at [37] et seq.

103 M. Husovec, 'Intellectual Property Rights and Integration by Conflict: The Past, Present and Future' (2016) 18 Cambridge Yearbook of European Legal Studies 239

104 Christina Angelopoulos, 'AG Szpunar in Stichting Brein v Ziggo: An Indirect Harmonisation of Indirect Liability’ (Kluwer Copyright Blog, 2017) available at < http://kluwercopyrightblog.com/2017/03/23/ag-szpunarstichting-brein-v-ziggo-indirect-harmonisation-indirect-liability/> (arguing this position) 


\section{Single or Lonely Market for the Online Enforcement?}

The website blocking injunctions became commonplace in the last couple of years. The national courts in countries such as the United Kingdom, ${ }^{105}$ Ireland, ${ }^{106}$ Belgium,,${ }^{107}$ Germany, ${ }^{108}$ Austria, ${ }^{109}$ Greece, ${ }^{110}$ France, ${ }^{111}$ Denmark,,${ }^{112}$ Finland ${ }^{113}$ and Italy, ${ }^{114}$ Sweden ${ }^{115}$ were reported to have considered such injunctions. However, the outcome of such cases greatly differs. As will be shown, the harmonization is far from being achieved.

The orders based on Article 8(3) of the InfoSoc Directive and Art 11, third sentence, of the Enforcement Directive surprised many national laws. Nothing illustrates this better than the fact that three governments - Dutch, British and German, mostly overlooked these far-reaching measures. The Dutch legislator did not pay attention to Article 8(3) of the InfoSoc Directive and only added corresponding provisions when prompted (again) by the Enforcement Directive. The United Kingdom first thought that implementation might be unnecessary, ${ }^{116}$ but

105 To name few: Twentieth Century Fox Film Corp v British Telecommunications plc (No 2) [2011] EWHC 2714 (Ch); Dramatico Entertainment Ltd v British Sky Broadcasting Ltd [2012] EWHC 268 (Ch); Dramatico Entertainment Ltd v British Sky Broadcasting Ltd (No 2) [2012] EWHC 1152 (Ch); EMI Records Ltd v British Sky Broadcasting Ltd [2013] EWHC 379 (Ch); Football Association Premier League Ltd v British Sky Broadcasting Ltd [2013] EWHC 2058 (Ch); Paramount Home Entertainment International Ltd v British Sky Broadcasting Ltd [2013] EWHC 3479 (Ch); Cartier International AG \& Ors v British Sky Broadcasting Ltd \& Ors [2014] EWHC 3354 (Ch).

106 EMI Records (Ireland) Ltd and others v. UPC Communications Ireland Ltd [2010] IEHC.

107 Belgian Court of Appeal of Antwerp, Belgian Anti-Piracy Foundation v. Belgacom and Telenet (2011) Case No. 2011/8314, available at https://edri.org/files/piratebay-decision-belgium-2011.pdf.

108 BGH Störerhaftung des Access-Providers (2015) I ZR 174/14; BGH (2015) I ZR 3/14

${ }^{109}$ Austrian Supreme Court, OGH (2014) 4Ob71/14s.

${ }^{110}$ See Editorial, 'the Court of First Instance of Athens (Monomeles Protodikio Athinon): "Security Measures Against ISPs"' [2013] IIC 468.

111 Tribunal de Grande Instance, Association des Producteurs de Cine'ma (APC) and others v. Auchan Telecom and others (2013) Case No 11/60013.

112 Danish Supreme Court, Telenor v. IFPI Denmark (2010) Case No. 153/2009, available at $<$ http://hssph.net/Sonofon_IFPI_DK_SupremeCourt_27May2010_PirateBay.pdf $>$. Accessed 5 July 2015.

113 Helsinki Court of Appeals, $(2012)$ Case S 11/3097; Helsinki Court of Appeals (2013) Case S 12/1825; Helsinki Court of Appeals (2013) Case S 12/2223; The Market Court (2016) Case 243/16.

114 AGCOM Regulations regarding Online Copyright Enforcement, 680/13/CONS December 12, 2013; Lazio Regional Administrative Tribunal, Tribunale Regionale Amministrativo (TAR) del Lazio, FEMI and Open Media Coalition v. Autorità per le Garanzie nelle Comunicazioni (AGCOM) (2014) Case No 2184/2014.

115 District Court in Stockholm (2015) AB T 15142-14; Swedish Patent and Market Court of Appeal, Patent- och Marknadsöverdomstolen (2017) PMT 11706-15.

116 The UK implemented Article 8(3) of the InfoSoc Directive by amending the 1988 Copyright Act and inserting the section 97A into the Copyright, Designs and Patents Act 1988 (CDPA) (by the Copyright and Related Rights Regulations 2003, SI 2003/2498), but did not pass any legislation to implement the third sentence of Article 11 of the Enforcement Directive. At first, however, the Government stated that: "Regarding Article 8.3, it is already possible under UK law to seek injunctions against intermediaries. It is also possible to notify an intermediary of an injunction served on an infringer so that the intermediary is liable for contempt of court proceedings if he aids and abets an infringer. It is considered that this meets the requirements of Article 8.3." (EC Directive 2001/29/EC on the Harmonisation of Certain Aspects of Copyright and Related Rights in the Information Society: Consultation Paper on Implementation of the Directive in the United Kingdom (Patent Office, 7 August 2002)). After the consultation, however, the Government changed its mind. It explained: "Right owner organisations generally expressed strong concern that, unless specific provision is made to implement Article 8.3, there would be 
then at least implemented copyright-specific provisions. The German government took the view that no changes in the law are necessary. ${ }^{117}$ If someone is to be credited for harmonization in this area, it should be the CJEU; certainly not the legislator(s). Given the wording of the provisions and lack of their comprehension at the time of domestic adoption, we would suggest that the judges have achieved a whole lot in a remarkably short time.

The CJEU significantly pushed harmonization further in its L'Oreal v eBay ${ }^{118}$ ruling where it permitted that domestic modalities survive only to the extent that they do not frustrate effet utile of the measures. This principle was accepted by the domestic courts to the extent that following the UPC Telekabel ruling, none of the highest national courts - German, Austrian, Swedish, English ${ }^{119}$ - even considered that website blocking is not prescribed by Union law. This is despite the fact that UPC Telekabel's framing was one of admissibility. ${ }^{120}$ Unanimously, it seems, the decision on effet utile was read as a signal of what the Court might consider an indispensable effective remedy. ${ }^{121}$

The application of the measures to access providers, in particular, surfaced the doctrinal reservations concerning the breadth of injunctions against intermediaries as well as domestic non-harmonized sediments. The lack of harmonization of accessory liability made its comeback as an issue when the domestic courts had to decide who a 'third party using the services to infringe' is. As shown by the Dutch example, this matters a lot and practically influences the scope of such injunctions. The set-up of the EU laws seems to have caused that domestic courts

\footnotetext{
uncertainty as to whether right owners can apply for injunctions, the more so because the Article 5.1 exception means that intermediaries will not themselves be infringing rights in the circumstances set out in that article. (..) 8.4 On further consideration, the Government has concluded that, in order to avoid uncertainty (..)" (Consultation on UK Implementation of Directive 2001/29/EC on Copyright and Related Rights in the Information Society: Analysis of Responses and Government Conclusions (Patent Office, 2003)).

117 See Stellungnahme der Bundesregierung vom 06.11.2002 im Rahmen der Umsetzung der Richtlinie - BTDrucksache 15/38, p. 39 (Anlage 3 ,Zu Buchstabe d“) available at < http://dip21.bundestag.de/dip21/btd/15/000/1500038.pdf>

118 Case C-324/09 L'Oréal v eBay [2011] ECR I-06011.

119 Austrian Supreme Court, OGH (2014) 4Ob71/14s, para 4.2; Cartier International AG \& Ors v British Sky Broadcasting Ltd \& Ors [2014] EWHC 3354 (Ch), para 121-132; Swedish Patent and Market Court of Appeal, Patent- och Marknadsöverdomstolen (2017) PMT 11706-15, para 25; BGH Störerhaftung des Access-Providers (2015) I ZR 174/14, para 40; BGH (2015) I ZR 3/14, para 37; for Dutch - see Part 3.

120 This is also confirmed by Justice Arnold's reading Cartier International AG \& Ors v British Sky Broadcasting Ltd \& Ors [2014] EWHC 3354 (Ch) at [174] ("the Court made it clear at [62] that the measures taken by the addressee of the injunction must at least have the effect of making access to the protected subject-matter difficult to achieve and of seriously discouraging internet users who are using the services of the addressee from accessing that subject-matter." - emphasis mine)

121 There is an undergoing discussion in the Union law about the relationship between a right to effective remedy and the principle of effectiveness - see Case C-73/16 Peter Puškár, Opinion of Advocate General Kokott, para 49 ("in recent times, the principle of effectiveness has increasingly been associated with the right to effective legal protection under Article 47(1) of the Charter. (19) In recent months, there have even been two relevant judgments, which are no longer based on the principle of effectiveness, but solely on Article 47(1)." - referring to Case C-439/14 and C-488/14 Star Storageand Others (ECJ, 15 September 2016), para 46; Case C-243/15 Lesoochranárske zoskupenie VLK (ECJ, 8 November 2016), para 65).
} 
are largely applying distinct concepts to achieve the identical enforcement goals. Moreover, the practice is subject to diverging conditions and modalities. The national practice differs in many crucial questions, including: a) who is considered to be an infringing third party, b) form of the orders, c) their specificity, d) scope of preventive duties, e) types of used technologies, f) possibility of ex-post submission upgrade, g) use of a subsidiarity principle, h) assessment of effectiveness, i) cost-allocation, j) post-grant supervision, k) locus standi for users and website operators and 1) the enforcement of court orders.

To give a small preview to substantiate this claim. French practice does not allow for ex-post submission of addresses, ${ }^{122}$ while English does. ${ }^{123}$ English courts treat accessories as 'third parties', while Dutch seem reluctant to go beyond categories of direct infringers. ${ }^{124}$ The German practice prescribes that access providers are targeted only after other means are properly exhausted, ${ }^{125}$ while Austrian, Dutch, English, French and Swedish courts don't require this. ${ }^{126}$ In the United Kingdom, the access providers are extensively forced to use advanced filtering techniques to achieve website blocking, while French courts are satisfied with DNS blocking. ${ }^{127}$ While French courts require reimbursement of the implementation costs, and such question is also hotly debated in the United Kingdom, ${ }^{128}$ the Dutch practice requires the access providers to reimburse the rightholders. German and Austrian practice doesn't grant any reimbursement of implementation costs. ${ }^{129}$

$122 \mathrm{Ch}$. Angelopoulos, European Intermediary Liability in Copyright: A Tort-Based Analysis (Kluwer Law International 2017) 228; Tribunal de Grande Instance, Association des Producteurs de Cine'ma (APC) and others v. Auchan Telecom and others (2013) Case No 11/60013

123 In a recent decision, Justice Arnold even accepted 'live blocking orders' - see The Football Association Premier League Ltd v British Telecommunications Plc \& Ors [2017] EWHC 480 (Ch) (13 March 2017)

124 Twentieth Century Fox Film Corp v British Telecommunications plc [2011] EWHC 1981 (Ch) (the website operator is secondarily liable for joint tortfeasorship and authorization of an infringement); Twentieth Century Fox Film Corp v British Telecommunications plc (No 2) [2011] EWHC 2714 (Ch); Dramatico Entertainment Ltd v British Sky Broadcasting Ltd [2012] EWHC 268 (Ch) [81], [83] (the website operator is secondarily liable for joint tortfeasorship and authorization of an infringement); Dramatico Entertainment Ltd $v$ British Sky Broadcasting Ltd (No 2) [2012] EWHC 1152 (Ch); EMI Records Ltd v British Sky Broadcasting Ltd [2013] EWHC $379(\mathrm{Ch}),[70]$, [74] (the website operator is secondarily liable for joint tortfeasorship and authorization of an infringement); Football Association Premier League Ltd v British Sky Broadcasting Ltd [2013] EWHC 2058 (Ch) [43] (the website operator is alternatively also secondarily liable for joint tortfeasorship); Paramount Home Entertainment International Ltd v British Sky Broadcasting Ltd [2013] EWHC 3479 (Ch) [35] (the website operator is alternatively also secondarily liable for joint tortfeasorship)

125 BGH Störerhaftung des Access-Providers (2015) I ZR 174/14, para 103; BGH (2015) I ZR 3/14, para 82.

126 Austrian Supreme Court, OGH (2014) 4Ob71/14s, para 3 (implicitly); Cartier International AG \& Ors $v$ British Sky Broadcasting Ltd \& Ors [2014] EWHC 3354 (Ch), para 197-217 (discussing alternative measures but rejecting all of them); Swedish Patent and Market Court of Appeal, Patent- och Marknadsöverdomstolen (2017) PMT 11706-15; Tribunal de Grande Instance, Association des Producteurs de Cine'ma (APC) and others $v$. Auchan Telecom and others (2013) Case No 11/60013; for Dutch - see above.

127 Tribunal de Grande Instance, Association des Producteurs de Cine'ma (APC) and others v. Auchan Telecom and others (2013) Case No 11/60013.

128 This aspect is currently pending before the Supreme Court of the United Kingdom,

129 See generally for the German situation - F. Hofmann, 'Markenrechtliche Sperranordnungen gegen nicht verantwortliche Intermediäre' [2015] GRUR 123; Austrian Supreme Court, OGH (2014) 4Ob71/14s, para 7. 
While Austrian courts see the locus standi of users in the remedies of the contract law, their English counterparts can apply to judges directly. ${ }^{130}$ Whereas English judicial orders are very specific in terms of technique and technology that should be used by a concrete defendant, the Austrian and likely German practice will only oblige to particular outcomes that are to be assessed in the follow-on proceedings. ${ }^{131}$ The Dutch courts specify the blocking technique, but not the exact technology that satisfies the orders. While English law punishes non-compliance with an injunction as a form of contempt, Dutch practice imposes automated fines and the Slovak laws would provide only for discretionary fines with a pre-set fine ceiling. ${ }^{132}$ These important issues undoubtedly influence the practice.

Apart from these practicalities, there are still open issues concerning the very assessment of proportionality and effectives of the measures. The Dutch saga, in particular when contrasted with English and German case law, shows that although the courts are using identical terms, they are often inherently applying different concepts or demonstrating their different understanding. While for the English High Court proportionality corresponds to the cost-benefit analysis after human rights are safeguarded, for the German BGH, it seems to imply rather constitutional balancing of the interests. ${ }^{133}$ Looking at the post-Telekabel period before the national courts, the CJEU's stance, despite its success for the harmonization, did not help in facilitating or construing a single platform for assessment.

The Dutch efficiency considerations at the Court of Appeals, which we sketched above, are thus telling. In line with the English assessment, it takes empirical analysis of costs and benefits as its starting point after clearing the basic fundamental rights issues. ${ }^{134}$ However, once the

\footnotetext{
${ }^{130}$ Austrian Supreme Court, OGH (2014) 4Ob71/14s, para 5.1; Cartier International AG \& Ors v British Sky Broadcasting Ltd \& Ors [2014] EWHC 3354 (Ch), para 262-265 (the orders are usually worded as follows: 'The operators of the Target Websites (as defined in the Schedule to this Order) and the operators of any other website who claim to be affected by this Order, are to have permission to apply on notice to vary or discharge this Order insofar as it affects such an applicant, any such application to be on notice to all the parties and to be supported by materials setting out and justifying the grounds for the application. Any such application shall clearly indicate the status of the applicant and indicate clearly (supported by evidence) that it is the operator of any website which is the subject of such application.')

131 Austrian Supreme Court, OGH (2014) 4Ob71/14s, para 5.2; for German case-law, see - BGH (2013) I ZR 79/12, para 21; BGH Störerhaftung des Access-Providers (2016) I ZR 174/14, para 14; BGH (2015) VI ZR 340/14, para 40 (this is part of its intentional efforts to capture also follow-on technological developments which could make the orders obsolete or less effective).

132 J. Riordan, The Liability of Internet Intermediaries (Oxford, 2016) 73, para 4.22 and 74, para 4.26; Customs and Exercise Commissioners v Barclays plc [2007] UKHL 28 at 17; For Dutch situation - see Part 3. Section 192(1) of the Act No. 233/1995 on Court Executors (Bailiffs) and Execution (so called Enforcement Procedure) sets a fine-ceiling of 30.000 EUR.

${ }^{133}$ See BGH Störerhaftung des Access-Providers (2015) I ZR 174/14, para 49; BGH (2015) I ZR 3/14, para 65.

${ }^{134}$ See for instance - Cartier International AG \& Ors v British Sky Broadcasting Ltd \& Ors [2014] EWHC 3354 (Ch), para 204 ('The key question, to my mind, is whether the benefits of website blocking, which accrue to the
} 
facts are established, the Dutch assessment, instead of weighing costs and benefits like English courts, slipped into a consideration where costs played a minor role, and disappointingly low benefits the major one. Unsurprisingly, this framing is a hard sell. If the instrument of injunctions against intermediaries exists in the law, it is hardly convincing, even as a matter of policy, to deny human rights conform injunctions in situations when evidence shows that their effectiveness offsets the costs. Unless there are long-term considerations, such as concerning future innovation that would speak against the grant, the effect of the measures is welfaremaximizing and regardless of how disappointingly small, the measure denial equals to a simple dismissal of the legislator's will.

The CJEU's 'do something' approach, ${ }^{135}$ as aptly called by Angelopulous, requires very low level of effectiveness. It did not, however, prescribe such standard as the only possible one. It has to be remembered that the UPC Telekabel decision and its low effectiveness threshold comes from the perspective of what is the minimum of effectiveness to satisfy the fundamental rights enquiry. Therefore, the decision says that the website blocking 'must be sufficiently effective to ensure genuine protection of the fundamental right at issue' ${ }^{136}$ in order to be permissible. The requirement that injunctions 'must have the effect of preventing unauthorised access to the protected subject-matter or, at least, of making it difficult to achieve and of seriously discouraging internet users ${ }^{\prime 137}$ is therefore a bare minimum. It would be a mistake to dismiss any higher threshold as immediately incompatible with Union law. An ability to set different costs-splits also affects availability, but, in absence of full unification, can be only challenged once it starts compromising the effet utile or effectiveness of the very essence of the remedy. However, the Dutch framing, which does not put the benefits into a perspective of costs, but only focuses on unspecified large benefits, appears to step exactly in the direction of such an extreme. It seems to compromise the very essence of the policy-choice and thus would likely not pass the razor of effet utile test of L'Oreal $v$ eBay. ${ }^{138}$

rightholders, justify the costs, and in particular the implementation costs which are imposed on the ISPs. This question is central to the assessment of proportionality.').

${ }_{135} \mathrm{Ch}$. Angelopoulos, European Intermediary Liability in Copyright: A Tort-Based Analysis (Kluwer Law International 2017) 227

136 Case C-314/12 UPC Telekabel Wien (ECJ 27 March 2014), para. 62.

137 Case C-314/12 UPC Telekabel Wien (ECJ 27 March 2014), para. 62.

138 This seems to be argued, though with much stronger implicit message, by AG, Szpunar in Case 610/15 Stichting Brein, para. 81 ("Acceptance of the reasoning of the defendants in the main proceedings would amount to accepting that no measure to prevent infringement of the law can be effective because new infringements will always be committed by other persons.") and para 83. This seems to build on the prior holding of the CJEU in McFadden, where the Court held that: "Since the two other measures have been rejected by the Court, to [reject 


\section{Conclusions}

At the 2016 Slovak EU presidency event held in Bratislava, entitled 'Shaping the Future [of IP] Expert Conference', Justice Arnold from the High Court of England delivered an intriguing talk about the state of website blocking. In his view, 'if greater consistency is to be achieved, a more harmonised legal framework is required'. ${ }^{139}$ My esteemed co-panellist in Berlin, Eleonora Rosati, whose contribution was also published in this journal earlier, also concludes that 'despite EU harmonization efforts in the area of IP enforcement, there are significant gaps in the resulting framework'. ${ }^{140}$ Indeed, the L'Oreal $v$ eBay-formula will not be able to solve all the discrepancies mentioned above. Even the prescriptiveness of the CJEU, whether based on Article 3 of the Enforcement Directive or the EU Charter provisions, has its limits. However, at the same time, it seems unrealistic that the EU legislator could solve all the areas where the dissonance exists. The breadth of the legal institutions influencing these practices ranges from the domestic ways of formulating and enforcing the orders to definition of who are accessories under domestic tort law. The positive harmonization has its cost and benefits as well. Rather than trying to unify everything, the energy of the legislator should be focused on few key aspects, in particular costs-allocation under the measures and the form in which the orders are granted and supervised against abuse. This is where the domestic legislators sometimes lack comprehension of the problem. The stakeholders can survive few domestic disparities as much as they have to survive the realities of the localized legal advice, but basic features of the system shouldn't differ, if we are serious about the instrument.

the third] would thus be to deprive the fundamental right to intellectual property of any protection, which would be contrary to the idea of a fair balance" (Case C-484/14 Mc Fadden (ECJ, 15 September 2016), para 98).

139 R. Arnold, IPRs Enforcement in the Digital Environment: Current UK practice and the need for further harmonisation (Talk in Bratislava: November 2016).

${ }^{140}$ E. Rosati, Intermediary IP Injunctions in the EU and UK Experiences: When Less (Harmonization) is More? (December 28, 2016). (Forthcoming) GRUR International 